\title{
IMPLIKASI PERATURAN MENTERI AGAMA NOMOR 56 TAHUN 2014 TERHADAP PERKEMBANGAN PASRAMAN
}

\author{
I Gede Suryawan ${ }^{1}$, I Wayan Sutama ${ }^{2}$ \\ STAHN Gde Pudja Mataram
}

\begin{abstract}
ABSTRAK
Pasraman merupakan salah satu ujung tombak lembaga pendidikan dan pembelajaran agama Hindu. Terbitnya PMA No. 56 tahun 2014 merupakan respon pemerintah dalam melindungi dan menata kegiatan pasraman. Penelitian ini bertujuan untuk mendeskripsikan aktivitas pengelolaan pasraman non formal sebelum adanya PMA, kendala yang dihadapi dalam mengelola pasraman dan implikasi terbitnya PMA terhadap pasraman non formal di kota Mataram. Penelitian ini menggunakan pendekatan deskriptif kualitatif, Teknik pengumpulan data menggunakan observasi, wawancara, dan dokumentasi. Teknik Analisis data menggunakan model Miler dan Huberman. Hasil penelitian menunjukkan aktivitas dan pengelolaan pasraman non formal sebelum penerapan PMA No. 56 tahun 2014 di kota Mataram adalah belum memiliki dasar hukum, Pengelolaan pasraman masih sederhana dan bersifat kekeluargaan, sarana dan prasarana pembelajaran belum memadai, dan belum adanya pembinaan dari lembaga manapun untuk meningkatkan mutu pengelolaan pasraman. Kendala yang dihadapi oleh pasraman non formal adalah: minimnya sosialisasi $P M A$, sulitnya mendapatkan tanda daftar, minimnya dukungan dana untuk mendukung kegiatan pasraman, dan belum adanya organisasi persatuan sebagai wadah komunikasi pasraman. Implikasi PMA adalah: meningkatnya motivasi mendapatkan tanda daftar sebagai legalitas organisasi, meningkatnya pengelolaan pasraman yang berbasis menejemen, meningkatnya dukungan orang tua siswa terhadap kegiatan pasraman, terbukanya akses rutin dalam pembiayaan, pembinaan, dan pengawasan dari lembaga pendidikan dan keagamaan, hadirnya organisasi persatuan pasraman (Perpasram) kota Mataram sebagai wadah komunikasi pasraman, dan keseragaman materi pembelajaran pasraman yang mengikuti kurikulum pendidikan.
\end{abstract}

Keywords : Pasraman; Pendidikan luar sekolah; menejemen pasraman; Implikasi PMA 56

\section{PENDAHULUAN}

Kota Mataram merupakan kota administratif dengan keanekaragaman budaya, suku, agama, dan ras. Masyarakat hidup dengan damai dalam keanekaragamannya, sehingga menjadi warna tersendiri dalam kehidupan penduduk di Kota Mataram. Masyarakat Hindu sebagai bagian dari warga kota Mataram berperan aktif dalam kehidupan sosial kemasyarakatan. Perkembangan kehidupan beragama di Kota Mataram yang telah terpelihara baik harus diteruskan kepada generasi penerus terutama anak-anak usia sekolah.

\footnotetext{
${ }^{1}$ Mahasiswa prodi Penerangan agama Hindu STAHN Gde Pudja Mataram

${ }^{2}$ Dosen Prodi Penerangan agama Hindu STAHN Gde Pudja Mataram
} 
Karena itu perlu adanya upaya yang keberlanjutan kegiatan keagamaan melalui pendidikan agama.

Anak-anak Hindu membutuhkan pendidikan agama, untuk membentuk pribadi yang berbudi pekerti luhur sesuai ajaran agama Hindu. Pendidikan agama saat ini diselenggarakan pada jalur formal dan non formal. Dalam jalur formal di jalankan di sekolah formal seperti SD, SMP, SMA dan lain-lain yang memiliki ijin resmi dari Pemerintah. Sedangkan pada jalur non formal dilaksanakan dalam bentuk Pesantian, Sad Dharma yaitu: Dharma Tula, Dharma Sedana, Dharma Wacana, Dharma Yatra, Dharma Gita, Dharma Santih atau dalam bentuk lainnya yang sejenis Padepokan, Aguron-Guron, Parampara, Guru Kula, Ashram (Tim Penyusun 2005: 17). Pendidikan agama pada jalur formal dirasakan masih kurang dalam meningkatkan sradha dan bhakti anak-anak yang beragama Hindu akibat minimnya guru agama Hindu yang ada di sekolah-sekolah formal. Akibatnya teori dan praktek keagamaan Hindu masih sangat minim.

Menyikapi persoalan tersebut, para pemerhati pendidikan dan tokoh agama beserta tokoh masyarakat Hindu lainnya berupaya membentuk lembaga pendidikan non formal sebagai wadah untuk mengajarkan dan meningkatkan pengetahuan agama Hindu bagi anakanak. Maka terbentuklah pasraman sebagai lembaga non formal. Raka (2006, 54) menyatakan bahwa peran pasraman sangat dibutuhkan di era globalisasi ini karena pasraman dijadikan wadah untuk menambah keterampilan agama atau praktek keagamaan. Hasil observasi awal menunjukkan pengelolaan pasraman di Kota Mataram masih sederhana dan bersifat kekeluargaan

Keberadaan pasraman di kota Mataram belum banyak dikenal oleh lingkungan masyarakat, khususnya umat Hindu. Dalam perjalanannya, pasraman di Kota Mataram mengalami perkembangan yang pasang surut. Berdasarkan data dari Penyelenggara BIMAS Hindu Kota Mataram jumlah pasraman non formal pada tahun 2015 sebanyak 21 pasraman. Tahun 2017 pembinaan mulai dilakukan oleh Penyelenggara BIMAS Hindu Kota Mataram dengan membentuk Perhimpunan Pasraman (Perpasram) Kota Mataram yang sebagai lembaga khusus dalam menangani permasalahan yang dihadapi oleh pasraman-pasraman di Kota Mataram dan pembinaan secara intensif sebagai penjabaran Peraturan Menteri Agama(PMA) nomor 56 tahun 2014 terhadap pasraman. Keberadaan PMA menyebabkan 
pasraman-pasraman di Kota Mataram bergeliat dan lebih termotivasi untuk mengembangkan lembaganya dengan berbagai kegiatan. Salah satu peran pemerintah yang telah di implementasikan guna mendukung PMA tersebut adalah rutin melaksanakan lomba jambore setiap tahun.

Penelitian yang dilakukan oleh Dharma, (2014) dengan judul "Pasraman Swasta Pranawa sebagai Media Komunikasi Anak-Anak Beragama Hindu di Lingkungan Abian Tubuh Cakranegara" menyatakan dasar hukum pendidikan pasraman didasarkan Surat Keputusan Direktur Jenderal Bimbingan Masyarakat Hindu dan Budha Nomor DJ.V/92/SK/2003 tentang penunjukan Parisada Hindu Dharma Indonesia sebagai Pasraman, sekolah minggu agama Hindu sebagai penyelenggara pendidikan agama Hindu tingkat sekolah dasar sampai dengan perguruan tinggi dan penetapan struktur kepengurusan Pasraman. Kegiatan pasraman Swasta Pranawa merupakan media komunikasi sebagai sarana mempersatukan anak-anak beragama Hindu di lingkungan Abiantubuh.

Penelitian Subagia, (2016) dengan judul " Keberadaan Pasraman Sebagai Penguatan Budaya Lokal dikaitkan dengan Peraturan Pemerintah Nomor 55 Tahun 2007" yang menyatakan upaya memanajemen pendidikan Hindu berbasis penguatan budaya lokal di pasraman dengan menggunakan metode pelajaran yang tepat sesuai dengan kurikulum yang berlaku. Penelitian lainnya, Budi, (2011) dengan penelitiannya "Peranan Pendidikan Pasraman Santi Aji di Lingkungan Keluarga Hindu Dusun Kembang Sari Desa Sepayung Kecamatan Plampang Kabupaten Sumbawa Besar" menyatakan peranan pendidikan pasraman sangat dirasakan keberadaan dan manfaatnya bagi umat Hindu yang ada melalui pola pendidikan Agama non formal. Penelitian ini bertujuan untuk mengetahui aktivitas pengelolaan pasraman, mengetahui kendala yang dihadapi dan mengetahui implikasi Peraturan Menteri Agama Nomor 56 Tahun 2014 di Kota Mataram.

\section{METODE PENELITIAN}

Penelitian ini menggunakan pendekatan kualitatif deskriptif, menggunakan analisis dengan pendekatan induktif. Lokasi penelitian dilaksanakan di kota Mataram dengan alasan jumlah penduduk beragama Hindu lebih banyak di Kota Mataram, memiliki Perhimpuan Pasraman (Perpasram) dan pasraman aktif dalam melakukan kegiatan. Jenis data yang 
digunakan data kuantitatif dan kualitatif. Data kuantitatif merupakan data statistik yang dipergunakan sebagai pendukung data kualitatif. Dari segi pengumpulan data diperoleh dari data primer dan data sekunder. Data primer diperoleh langsung dari objek yang akan diteliti (responden). Sedangkan data sekunder diperoleh dari pengurus-pengurus pasraman maupun pertemuan antar pasraman-pasraman di Kota Mataram. Teknik pengumpulan data menggunakan observasi, wawancara, dan dokumentasi. Teknik Analisis data yang digunakan menggunakan model Miller dan Huberman dalam Basrowi dan Suwandi (2008: 209) yang mencakup tiga kegiatan yang bersamaan yaitu: reduksi data, untuk menajamkan, menggolongkan, mengarahkan, membuang yang tidak perlu, dan mengorganisasi sehingga interpretasi bisa ditarik, dilanjutkan dengan penyajian data berupa teks naratif, matrik, grafik, jaringan dan bagan untuk memudahkan membaca dan menarik kesimpulan dan terakhir penarikan kesimpulan.

\section{HASIL DAN PEMBAHASAN}

Implikasi peraturan Menteri Agama Nomor 56 Tahun 2014 dalam penelitian ini adalah konsekuensi yang muncul akibat terbitnya PMA sebagai kebijakan yang dapat bersifat baik atau tidak baik terhadap kehidupan hidup masyarakat. Dalam konteks ini peraturan yang dikeluarkan oleh Kementerian Agama Republik Indonesia digunakan untuk mengatur keberadaan Pasraman Sehingga pasraman yang ada akan mudah didata untuk diberikan anggaran dana dan melakukan pembinaan. Pasraman merupakan tempat untuk melakukan kegiatan belajar. Pasraman dapat berbentuk formal maupun non formal. Bentuk formal maksudnya pasraman yang dikelola dalam sistem manajemen dan pengadministrasian secara formal atau resmi oleh pemerintah maupun dalam bentuk yayasan. Sedangkan bentuk non formal adalah pasraman yang dikelola sepenuhnya oleh masyarakat dalam bentuk pelatihan. Pendidikan pasraman menekankan pada disiplin diri, mengembangkan akhlak mulia dan sifat-sifat yang rajin, suka bekerja keras, pengekangan hawa nafsu dan gemar menolong orang lain. Konsep pasraman yang berkembang diadopsi dari sistem pendidikan Hindu dari jaman dahulu di India sebagai mana disuratkan dalam kitab suci Veda dan hingga kini masih tetap terpelihara (Tim Penyusun 2005: 5). 
Pasraman di Indonesia telah muncul dan berkembang dengan pesat. Kehadiran pasraman ini bertujuan untuk mengantisipasi berbagai permasalahan yang dihadapi oleh umat Hindu terutama masalah pendidikan Agama Hindu. Keterbatasan tenaga guru Agama Hindu membuat hak anak-anak Hindu menjadi terabaikan. Pendidikan agama yang diperoleh di sekolah-sekolah pada umumnya dirasakan kurang, sehingga siswa diharapkan mengikuti pendidikan Agama Hindu melalui lembaga pasraman. Perkembangan pasraman di Kota Mataram mulai meningkat, ini terbukti dari data yang diperoleh dari Penyelenggara Bimas Hindu Kota Mataram.

Konsep perkembangan yang dimaksud adalah pengembangan dan pengelolaan pasraman yang lebih baik. Dilihat dari sisi pembinaan, pemerintah kota dalam hal ini penyelenggara bimas Hindu Kota Mataram telah membentuk lembaga yang mengawasi dan menangani masalah pasraman di Kota Mataram. Pasraman yang dibahas dalam konteks ini adalah pasraman di Kota Mataram yang terbagi dalam 2 jenis yaitu pasraman formal dan non formal.

Adapun teori yang digunakan untuk menjawab permasalahan terdiri dari 2 teori yaitu teori manajemen kinerja dan teori fungsional. Teori manajemen kinerja digunakan membedah permasalahan aktivitas pengelolaan pasraman non formal dan kendala yang dihadapi. Sedangkan teori fungsionalis digunakan untuk mengetahui implikasi PMA 56 tahun 2014. Manejemen kinerja berhubungan dengan pekerjaan individu sehingga mereka dapat memanfaatkan kemampuannya sebaik-baiknya, menyadari potensi diri dan memaksimalkan kontribusi mereka terhadap keberhasilan organisasi. Sedangkan teori fungsionalis menurut William Ogbrun menjelaskan perubahan sosial merupakan suatu yang konstan dan tidak memerlukan penjelasan, oleh karena itu perubahan sosial bisa saja mengacaukan suatu keseimbangan dalam masyarakat. Teori ini digunakan untuk mengetahui perubahan dalam segi pengawasan, pembinaan, administrasi, dan pembiayaan pasraman di Kota Mataram dikarenakan turunnya PMA no. 56 tahun 2014.

\section{Aktivitas dan pengelolaan Pasraman non formal sebelum Penerapan PMA}

Hasil dokumentasi dan wawancara menunjukkan kegiatan pengelolaan pasraman sebelum adanya PMA No. 56 tahun 2014 di Kota Mataram adalah sebagai berikut: Dalam konteks perencanaan (planning) terdapat beberapa kondisi yaitu : Pengurus belum memiliki 
konsep yang jelas dilihat dari penyiapan tempat kegiatan, belum memiliki kurikulum pembelajaran yang disepakati bersama dan belum memiliki dasar hukum yang melindungi kegiatan pasraman. Dalam konteks pengorganisasian (organizing): pengelolaan pasraman masih sederhana sesuai kemampuan pengurus dan bersifat kekeluargaan, pengajar terbatas dan bersifat sukarela, siswa menggunakan busana adat dalam kegiatan pembelajaran dan tidak adanya koordinasi antar pasraman di kota Mataram. Dalam konteks pelaksanaan (actuating) : kegiatan pasraman belum terfokus pada tujuan utama yaitu pembelajaran agama dan cenderung mengarah pada pembelajaran seni dan budaya, siswa yang belajar belum dikelompokkan sesuai kategori umur, kegiatan dilaksanakan pada hari libur atau hari minggu, lokasi kegiatan pasraman menggunakan areal pura atau banjar, belum adanya dukungan penuh dari orang tua siswa dan kegiatan pasraman berlangsung pasang surut. Konteks pengawasan dan evaluasi ( controlling and evaluating) kegiatan pasraman belum ada lembaga yang mengawasi dan melakukan monitoring terhadap pasraman yang ada, juga belum ada lembaga yang melakukan pembinaan untuk meningkatkan kinerja pasraman.

Aktivitas dan pengelolaan pasraman di Kota Mataram sebelum PMA No. 56 tahun 2014 dilihat dari teori manajemen kinerja yang mensyaratkan sebuah proses manajemen kinerja yang menetapkan tujuan yang hendak dicapai, pendekatan untuk pengelolaan dan pengembangan manusia yang dapat meningkatkan sasaran dan tujuan baik dalam jangka pendek dan dalam jangka panjang. Pengelolaan pasraman di Kota Mataram menurut teori manajemen kinerja belum terlaksana secara maksimal.

Unsur-unsur manajemen kinerja yang dilihat dari hasil penelitian ini adalah belum adanya kerangka kerja dari sasaran yang direncanakan, standar, kompetensi yang telah disepakati. Manajemen kinerja tidak berjalan sebagai mana mestinya di mana kesepakatan antara pendidik dan para pimpinan tentang kerangka kerja pasraman belum maksimal. Pengelolaan lebih banyak dilakukan oleh para pimpinan pasraman sehingga tidak sinkron dengan pendidik. Wawancara dengan pengurus pasraman yang ada di Kota Mataram menunjukkan pengelolaan pasraman masih dikelola oleh sebagian besar pengurus pasraman dan para Acarya yang mengalami berbagai kendala seperti tingkat kehadiran yang belum konsisten. Hal ini membuat komunikasi antara pengurus pasraman tidak berjalan baik, menyebabkan kurang maksimalnya proses pembelajaran. 
Unsur selanjutnya adalah menejemen kinerja. Menejemen kinerja bukan hanya sebatas serangkaian sistem formulir atau prosedur melainkan serangkaian tindakan yang harus diambil untuk mencapai tujuan dan mengelola peningkatan kinerja diri mereka sendiri maupun orang lain. Pasraman di Kota Mataram belum menerapkan sistem manajemen kinerja, dimana pengelolaan menggunakan sistem kekeluargaan. Pasraman belum melakukan pengembangan dilihat dari aktivitas pasraman yang masih minim baik dari sisi materi pembelajaran dan sisi acarya yang tidak sesuai dengan klasifikasi yang diinginkan.

Unsur yang ketiga yaitu pemahaman bersama untuk memperbaiki kinerja. Para individu harus memiliki pemahaman yang sama bagaimana seharusnya bentuk tingkat kinerja dan kompetensi yang tinggi serta ketercapaian tujuan. Pengurus pasraman belum memiliki pengetahuan yang sama secara komprehensif sehingga tingkat kinerja para pengurus pasraman kurang kompeten menyebabkan ketercapaian tujuan pasraman belum maksimal. Pengelolaan pasraman yang masih dikelola tanpa ada keseragaman dalam kegiatan dikarenakan kurang melakukan koordinasi antara pengurus maupun dengan kementerian agama. Akibatnya adalah pasraman-pasraman yang ada di kota Mataram belum memiliki keseragaman dari segi administrasi maupun pengelolaan pasraman.

Unsur yang keempat adalah pendekatan dalam mengelola dan mengembangkan SDM. Kepemimpinan organisasi pasraman di Mataram kurang efektif karena dalam pengelolaan masih bersifat kekeluargaan. Pengurus pasraman dalam merekrut Acarya tersebut tidak sesuai dengan materi yang diajarkan oleh Acarya tersebut. Akibatnya adalah Acarya dalam memberikan materi pelajaran keagamaan terlihat tidak kompeten sesuai bidangnya. Ini terlihat dari tamatan Acarya yang tidak sesuai dengan ilmu keagamaan sebagaimana yang diharapkan. Selain itu kerja sama pimpinan pasraman dengan segenap pengurus belum berjalan dengan baik dikarenakan pengurus pasraman yang masuk dalam struktur organisasi tidak sesuai dengan fungsinya. Manajemen pasraman tidak dikelola oleh pengurus-pengurus yang sesuai dengan tugasnya. Dalam hal pengembangan kompetensi untuk meningkatkan pengetahuan, keahlian dan profesionalisme pengurus pasraman di Kota Mataram belum ada strategi dan upaya yang sistematis menyebabkan pasraman dan kegiatannya mengalami pasang surut. 
Unsur yang kelima yaitu pencapaian. Seluruh aktifitas kinerja individu dan pencapaian yang telah dimiliki harus dapat dimanfaatkan untuk memaksimalkan kontribusi mereka terhadap keberhasilan organisasi. Aktifitas Pasraman di Kota Mataram itu tidak berjalan secara maksimal karena belum ditunjang sarana dan prasarana yang memadai. Kegiatan pasraman yang belum maksimal membuat pengembangan bakat dan keterampilan yang dimiliki oleh siswa kurang maksimal. Akibatnya tujuan utama pasraman dalam mengembangkan ilmu keagamaan sesuai dengan fungsinya.

Teori manajemen kinerja berkaitan dengan usaha, kegiatan, atau program yang diprakarsai dan dilaksanakan oleh pimpinan organisasi untuk merencanakan, mengarahkan dan mengendalikan prestasi karyawan. Secara teknis manajemen kinerja dimulai dengan menetapkan tujuan dan sasaran yaitu kinerja dalam bentuk apa dan yang seperti bagaimana yang ingin dicapai (Ruky, 2002). Manajemen kinerja mensyaratkan suatu upaya dan strategi yang fokus pada tujuan pasraman sebagai tempat pembelajaran ilmu, seni budaya dan agama Hindu. Untuk itu dibutuhkan strategi perencanaan yang dapat dilakukan dalam jangka pendek maupun jangka panjang. Pengelolaan dan peningkatan kompetensi pengurus harus dilakukan secara sistematis dan berkelanjutan agar kinerja pasraman terarah. Dengan terbitnya PMA No. 56 tahun 2014, secara perlahan diharapkan terjadi perubahan yang sistematis bagi pasraman non formal di kota Mataram. Pembinaan yang selama ini dilakukan oleh Kementerian Agama Republik Indonesia setelah terbitnya PMA no. 56 Tahun 2014 yang isinya memuat tentang aturan dalam membentuk pasraman formal dan non formal, pengelolaan, pembinaan dan pengawasan agar pasraman dapat menjadi sarana untuk turut mencerdaskan kehidupan bangsa terutama dalam konteks pembelajaran agama, seni budaya Hindu bagi masyarakat Hindu.

\begin{tabular}{|l|l|l|l|}
\hline No. & \multicolumn{1}{|c|}{ Nama Pasraman } & \multicolumn{1}{|c|}{ Kelurahan } & \multicolumn{1}{|c|}{ Kecamatan } \\
\hline 1 & Pasraman Sad Dharma Dwijendra & Pagutan Timur & Mataram \\
\hline 2 & Pasraman Yowana Pasupati & Mataram Timur & Mataram \\
\hline 3 & Pasraman Widya Yowana & Mataram Timur & Mataram \\
\hline 4 & Pasraman Dharma Tirtha & Pagutan Timur & Mataram \\
\hline 5 & Pasraman Dharma Paramitra & Karang Baru & Mataram \\
\hline
\end{tabular}




\begin{tabular}{|l|l|l|l|}
\hline 6 & Pasraman Mudita Santih & Punia & Mataram \\
\hline 7 & Pasraman Tunggal Kayun & Karang Baru & Mataram \\
\hline 8 & Pasraman Widya Sakti Astapaka & Cakranegara Timur & Cakranegara \\
\hline 9 & Pasraman Sakya Muni & Cilinaya & Cakranegara \\
\hline 10 & Pasraman Samiaga & Cakra Selatan & Cakranegara \\
\hline 11 & Pasraman Dharma Putra & Cakra Utara & Cakranegara \\
\hline 12 & Pasraman Giribajing & Cakra Utara & Cakranegara \\
\hline 13 & Pasraman Saraswati & Babakan & Cakranegara \\
\hline 14 & Pasraman Vidya Prasanthi & Karang Taliwang & Cakranegara \\
\hline 15 & Pasraman Eka Dharma & Babakan & Cakranegara \\
\hline 16 & Pasraman Swasta Pranawa & Abiantubuh & Sanubaya \\
\hline 17 & Pasraman Mustika Dharma & Pagesangan & Sanubaya \\
\hline 18 & Pasraman Widya Santa Dharma & Selagalas & Sanubaya \\
\hline 19 & Pasraman Ayodya Sumanasantaka & Mataram & Selaparang \\
\hline 20 & Pasraman Varitra Saraswati & Mataram & Sekarbela \\
\hline 21 & Pasraman Dharma Praweti & Pasraman Dang Hyang Sidhi Mantra & Tajung Karang \\
\hline 23 & Pasraman Saraswati Tri Paratha & Tanjung Karang Permai & \\
\hline
\end{tabular}

Tabel : Nama Pasraman di Kota Mataram

Sumber: Penyelenggara BIMAS Hindu Kota Mataram

\section{Kendala dalam Mengimplementasikan PMA no. 56 tahun 2014.}

Kendala dalam mengimplementasikan PMA no. 56 tahun 2014 sebagaimana hasil observasi dan wawancara yang dilakukan kepada pengurus pasraman adalah: (1) Tidak mudah dalam mendapatkan tanda daftar dari Dirjen Bimas Hindu karena kesulitan dalam memenuhi berbagai persyaratan yang ditetapkan; (2) minimnya sosialisasi yang dilakukan dari pihak terkait terutama oleh Bidang Bimas Hindu menyebabkan pengurus Pasraman 
belum memahami secara komprehensif mengenai PMA no. 56 tahun 2014 dan dampaknya bagi pasraman; (3) Minimnya jumlah acarya yang sesuai ketentuan dalam PMA dan kualifikasi pengajar pasraman yang tidak sesuai bidang keilmuan; (4) Minimnya sumber pendanaan pasraman dalam menunjang kegiatan terutama untuk operasional, dan pemenuhan sarana dan prasarana yang diperlukan dalam kegiatan pasraman menyebabkan dana untuk memenuhi dan mengurus persyaratan tanda daftar tersebut harus diupayakan dulu.

Bila dilihat dari teori manajemen kinerja yang berfokus pada upaya dan strategi pencapaian tujuan organisasi secara maksimal, maka unsur-unsur yang terkait harus dilaksanakan secara sistematis. Dalam konteks pasraman ada unsur-unsur yang mempengaruhi stagnasi perkembangan pasraman yaitu: (1) Menejemen kinerja merupakan strategi pengelolaan secara demokratis antar pengurus sehingga harapan pengurus semua dapat terakomodir. Apabila semua pengurus pasraman memiliki kesadaran dan tujuan yang sama dalam mengelola dan mengembangkan pasraman, maka berbagai kesulitan yang dihadapi niscaya akan dapat diselesaikan bersama-sama secara demokratis. Terlebih lagi dalam pendanaan yang menghambat jalannya kegiatan pasraman, pengurus dapat bersamasama mencari solusi yang cerdas. Sebagaimana diketahui, kegiatan pasraman membutuhkan sarana dan prasarana untuk mendukung aktivitas pembelajaran di pasraman; (2) Manajemen kinerja bukan hanya serangkaian sistem formulir dan prosedur, melainkan serangkaian tindakan yang harus diambil untuk mencapai suatu hasil atau tujuan yang diharapkan.

Terkait dengan serangkaian tindakan yang diambil untuk mencapai peningkatan kinerja, tentunya pasraman yang ada di Kota Mataram tersebut memiliki kendala dalam meningkatkan kinerja. Minimnya pengetahuan dan pemahaman terhadap PMA membuat sistem pengelolaan pasraman belum menunjukkan perkembangan ke arah yang lebih baik. Dengan demikian, pengelolaan yang seharusnya semakin modern namun malah jalan di tempat menggunakan sistem kekeluargaan sehingga sulit meningkat kinerjanya dan cenderung tertinggal; (3) Minimnya pemahaman bersama akan PMA membuat pengurus pasraman di Kota Mataram gamang dalam menentukan langkah bersama menjadikan pasraman sebagai salah satu sarana mencerdaskan anak bangsa. Hal ini karena sistem pengelolaan masih bersifat kekeluargaan; (4) Manajemen kinerja berfokus pada tiga hal. Pertama, cara menejer dan pimpinan dalam bekerja secara efektif dengan orang-orang yang 
ada di sekitarnya; kedua, cara bekerja sama antar individu dengan para menejernya; ketiga, cara individu dalam meningkatkan mutu kinerjanya. Minimnya sosialisasi ke lingkungan sekitar pasraman, membuat program kerja yang dibuat pengurus tidak terlaksana maksimal. Di samping itu kerja sama dan komunikasi antar pengurus masih minim sehingga fungsi dan tugas masing-masing pengurus tidak sesuai. Di samping itu kerjasama antar pengurus dengan pimpinan tidak berjalan baik dan sering miskomunikasi. Pengembangan kompetensi individu untuk meningkatkan mutu kinerja juga masih terkendala dari minimnya sarana prasarana yang mendukung materi pembelajaran; (5) Unsur yang kelima adalah pencapaian yang berhubungan dengan pekerjaan individu sehingga mereka dapat memanfaatkan kemampuannya secara maksimal.

\section{Implikasi PMA No. 56 tahun 2014 terhadap pasraman non formal}

Hasil wawancara yang dilakukan menunjukkan beberapa implikasi terkait hadirnya payung hukum pasraman dalam PMA No. 56 tahun 2014. Implikasi tersebut adalah: (1) Pasraman non formal di Kota Mataram lebih termotivasi dalam melegalkan pasramannya. Selain untuk meningkatkan mutu dan kualitas pengelolaan pasraman, juga untuk menunjukkan eksistensi pasraman tersebut di daerah maupun secara nasional dengan mengikuti berbagai lomba yang diselenggarakan bimas Hindu sehingga terdaftarnya pasraman akan memberikan keuntungan baik secara langsung maupun tidak langsung; (2) mendapatkan pembinaan yang berkelanjutan dari Bimas Hindu dan lembaga lainnya sehingga secara bertahap dapat meningkatkan kinerja organisasi; (3) Memiliki badan hukum yang jelas sehingga akan mendapatkan perlindungan hukum; (4) Organisasi lebih tertata secara administrasi karena PMA tersebut mewajibkan pasraman untuk tertib administratif untuk meningkatkan tata kelola dan memudahkan evaluasi kegiatan; (5) dengan terdaftar, orang tua mendukung dan percaya untuk mengikutkan anaknya belajar di Pasraman; (6) Bantuan pendanan untuk pasraman lebih terarah dan dapat di pertanggungjawaban secara akuntabel; (7) Mempermudah akses bantuan dari lembaga-lembaga formal maupun dari pemerintah terutama dari Dirjen Bimas Hindu sebagai alternatif sumber pendanaan guna melengkapi sarana dan prasarana yang dibutuhkan untuk pembelajaran; (8) Brahmacari lebih termotivasi dan aktif dalam mengikuti kegiatan pasraman sebagai sarana meningkatkan pengetahuan agama Hindu, seni dan budaya.; (9) Meningkatnya jumlah pasraman aktif di 
kota Mataram yang awalnya aktif 5, kini bertambah menjadi 23 pasraman; (10) Pembinaan berkala atau rutin dari Bimas Hindu terhadap pasraman di Kota Mataram; (12) Memberikan harapan terhadap umat Hindu untuk membuat sekolah bernuansa Hindu baik formal maupun non formal sebagai sarana generasi Hindu mengembangkan diri dalam bidang agama; (13) Terbentuknya Perhimpunan Pasraman (Perpasram) Kota Mataram sebagai wadah bersama mengembangkan pasraman; (14) Penambahan hari dalam kegiatan pasraman yang awalnya 1 kali dalam seminggu, kini menjadi 3 kali seminggu; (15) Pengelolaan Pasraman bekerja sama dengan Kementerian Agama di antaranya dengan merekrut pengajar sebagai penyuluh non PNS; (16) Keseragaman materi pembelajaran pasraman yang di lombakan.

Implikasi PMA No. 56 tahun 2014 bila dikaji dari perspektif teori fungsionalis hanya menerima perubahan yang menguntungkan atau bermanfaat bagi masyarakat. Teori fungsionalis struktural yang mendasarkan pandangan kepada keutuhan masyarakat beranggapan bahwa keterkaitan fungsi dan peran antara pihak-pihak yang berkepentingan dalam memajukan pendidikan agama merupakan unsur yang berpengaruh di dalam keutuhan masyarakat (Zamroni, 2013). Peran pasraman tidak didasari oleh disrupsi dan kompetisi tetapi lebih kepada melestarikan harmonisasi dan stabilitas di masyarakat dalam bidang pendidikan, seni dan budaya keagamaan Hindu.. Di sisi manajemen dan aktifitas pasraman, perkembangan pasraman saat ini dipengaruhi oleh PMA sebagai landasan hukum yang memberikan penguatan dan motivasi dalam pengelolaan pasraman yang lebih profesional.

\begin{tabular}{|l|l|c|c|c|}
\hline No & \multicolumn{1}{|c|}{ Nama Pasraman } & Status & $\begin{array}{c}\text { Tanda } \\
\text { Daftar }\end{array}$ & $\begin{array}{c}\text { Tahun } \\
\text { Berdiri }\end{array}$ \\
\hline 1. & Pasraman Sad Dharma Dwijendra & Aktif & Ada & 2005 \\
\hline 2. & Pasraman Swasta Pranawa & Aktif & Ada & 2012 \\
\hline 3. & Pasraman Saraswati Tri Paratha & Aktif & Tidak Ada & 1987 \\
\hline 4. & Pasraman Yowana Pasupati & Aktif & Tidak Ada & 2018 \\
\hline 5. & Pasraman Vidya Yowana & Aktif & Tidak Ada & 2017 \\
\hline 6. & Pasraman Samiaga & Aktif & Tidak Ada & 2016 \\
\hline 7. & Pasraman Dharma Putra & Aktif & Tidak Ada & 2003 \\
\hline
\end{tabular}




\begin{tabular}{|c|c|c|c|c|}
\hline 8. & Pasraman Giribajing & Aktif & Tidak Ada & 2018 \\
\hline 9. & Pasraman Saraswati & Aktif & Tidak Ada & 2011 \\
\hline 10. & Pasraman Vidya Prasanthi ( Widya Dharma) & Aktif & Tidak Ada & $2013 / 2018$ \\
\hline 11. & Pasraman Eka Dharma & Aktif & Tidak Ada & 2006 \\
\hline 12. & Pasraman Mustika Dharma & Aktif & Tidak Ada & 2004 \\
\hline 13. & Pasraman Widya Santa Dharma & Aktif & Tidak Ada & 2013 \\
\hline 14. & Pasraman Varitra Saraswati & Aktif & Tidak Ada & 2015 \\
\hline 15. & Pasraman Widya Sakti Astapaka & Pasif & Tidak Ada & 2017 \\
\hline 16. & Pasraman Sakya Muni & Pasif & Tidak Ada & 2002 \\
\hline 17. & Pasraman Dang Hyang Sidhi Mantra & Pasif & Tidak Ada & 2004 \\
\hline 18. & Pasraman Ayodya Sumanasantaka & Pasif & Tidak Ada & 2017 \\
\hline 19. & Pasraman Dharma Tirtha & Tidak Aktif & Tidak Ada & - \\
\hline 20. & Pasraman Dharma Paramitra & Tidak Aktif & Tidak Ada & - \\
\hline 21. & Pasraman Mudita Santih & Tidak Aktif & Tidak Ada & - \\
\hline 22. & Pasraman Tunggal Kayun & Tidak Aktif & Tidak Ada & - \\
\hline 23. & Pasraman Dharma Praweti & Tidak Aktif & Tidak Ada & - \\
\hline
\end{tabular}

Tabel : Status Pasraman di Kota Mataram

Sumber : Penyelenggara BIMAS Hindu Kota Mataram

Teori fungsionalis (functionalist theory) merupakan konsep yang berkembang dari teori ini adalah cultural lag (kesenjangan budaya). Konsep ini mendukung Teori fungsionalis untuk menjelaskan perubahan sosial tidak lepas dari hubungan antara unsur-unsur kebudayaan dalam masyarakat. Menurut teori ini, beberapa unsur kebudayaan bisa saja berubah dengan sangat cepat sementara unsur yang lainnya tidak dapat mengikuti kecepatan perubahan unsur tersebut. Maka, yang terjadi adalah ketertinggalan unsur yang berubah secara perlahan tersebut. Teori Fungsionalis lebih menerima perubahan sosial sebagai sesuatu yang konstan (tetap) dan tidak memerlukan penjelasan. Perubahan dianggap sebagai suatu hal yang mengacaukan keseimbangan masyarakat sehingga hal ini menyebabkan 
penerimaan konsep pasraman menemui resistensi di tengah-tengah masyarakat yang minim informasi.

Perkembangan pasraman saat ini mengalami perkembangan yang positif baik dari segi kuantitatif dan segi kualitatif. Dari segi kuantitatif bisa dilihat dengan semakin banyaknya pasraman yang berdiri dan dikelola masyarakat, sedangkan dari sisi kualitatif bisa dilihat dengan semakin baiknya pengelolaan pasraman dengan menerapkan prinsip-prinsip manajemen yang sistematis dan akuntabel. Hal ini dikarenakan tuntutan dari keberadaan PMA yang berorientasi pada kinerja mutu agar output yang dihasilkan pasraman memberikan kontribusi dalam mewujudkan cita-cita bangsa dalam mencerdaskan masyarakat. Dengan pengelolaan yang professional, output peserta didik yang dihasilkan juga akan semakin baik dengan peningkatan pemahaman pengetahuan agama Hindu yang lebih bermuara pada karakterisasi nilai Hindu yang akan menjadi pondasi bagi generasi Hindu. Pembinaan dan pengelolaan yang melibatkan Bimas Hindu dapat menjadi simbiosis mutualisme dalam membimbing masyarakat. Pasraman dapat menjadi partner pemerintah dalam upaya memasyarakatkan nilai dan ajaran agama Hindu bagi generasi muda.

\section{SIMPULAN}

Hasil analisis dari penelitian ini disimpulkan sebagai berikut. Aktivitas dan pengelolaan Pasraman non formal sebelum penerapan PMA No. 56 tahun 2014 di kota Mataram adalah sebagai berikut: (1) Pasraman belum memiliki dasar hukum yang jelas; (2) Pengelolaan pasraman masih sederhana dan bersifat kekeluargaan dengan memanfaatkan areal pura atau banjar sebagai tempat aktivitas; (3) Pembelajaran dilakukan dengan sederhana dengan memanfaatkan sarana dan prasarana yang ada; (4) Belum adanya pembinaan dari lembaga manapun untuk meningkatkan mutu pengelolaan pasraman.

Kendala yang dihadapi oleh pasraman non formal di Kota Mataram dalam mengimplementasikan PMA No. 56 tahun 2014 adalah: (1) minimnya sosialisasi PMA yang dilakukan kepada masyarakat ; (2) sulitnya mendapatkan tanda daftar dari Dirjen Bimas Hindu karena berbagai persyaratan yang harus dipenuhi; (3) minimnya dukungan dana untuk mendukung kegiatan pasraman serta memenuhi sarana dan prasarana yang menjadi 
persyaratan tanda daftar; (4) belum adanya organisasi persatuan yang memayungi dalam pembinaan dan pengawasan pasraman.

Implikasi PMA no. 56 tahun 2014 terhadap pasraman non formal di Kota Mataram adalah sebagai berikut : (1) peningkatan motivasi untuk mendapatkan tanda daftar sebagai bentuk legalitas organisasi agar dapat mengakses bantuan pendidikan dari lembaga formal ; (2) peningkatan pengelolaan pasraman berbasis menejemen sehingga lebih tertata secara administrasi, akuntabel dan profesional dalam pengelolaan; (3) meningkatnya dukungan orang tua siswa terhadap kegiatan pasraman; (4) mendapatkan akses rutin dalam pembiayaan, pembinaan, dan pengawasan dari lembaga pendidikan dan keagamaan terutama Bimas Hindu; (5) hadirnya organisasi persatuan pasraman (Perpasram) kota Mataram sebagai wadah komunikasi pasraman; (6) meningkatnya kegiatan pasraman yang semula 1 kali seminggu kini bisa 3 kali seminggu sehingga siswa aktif mengikuti kegiatan; (7) beberapa pasraman dikelola oleh lembaga atau yayasan resmi atau bekerja sama dengan Bimas Hindu sehingga meningkatkan jumlah pasraman; (8) keseragaman materi pembelajaran pasraman yang mengikuti kurikulum pendidikan.

\section{DAFTAR PUSTAKA}

Budi, I Made. 2011. Peranan Pendidikan Pasraman Santi Aji di Lingkungan Keluarga Hindu Dusun Kembang Sari Desa Sepayung Kecamatan Plampang Kabupaten Sumbawa Besar ( Skripsi). Jurusan pendidikan STAHN Gde Pudja Mataram.

Dharma, I Gede Adi Wira. 2014. Pasraman Swasta Pranawa Sebagai Media Komunikasi Anak-Anak Beragama Hindu di Lingkungan Abiantubuh Cakranegara (Skripsi). Jurusan penerangan. STAHN Gde Pudja Mataram.

Raka. I Nyoman. 2006. Aspek Manajemen Pasraman Hindu di Kota Mataram (Jurnal Ilmiah). STAHN Gde Pudja Mataram.

Subagia, I Nyoman 2016 p-ISSN: 2460-3376, e-ISSN:2460-44445. Keberadaan Pasraman Sebagai Penguatan Budaya Lokal dikaitkan Dengan Peraturan Pemerintah Nomor 55 Tahun 2007 (Jurnal). Institut Hindu Dharma Negeri Denpasar.

Barsuwi \& Suwandi. 2008. Memahami Penelitian Kualitatif. Jakarta: Rineka Cipta.

Ruky, A. S. (2002). Sistem manajemen kinerja. Gramedia Pustaka Utama. 
Tim Penyusun. 2005. Pedoman Penyelengaraan Pasraman. Surabaya: paramita.

Syahputra, F. A. (2018). Dampak Sistem Manajemen Kinerja terhadap Kinerja Karyawan. Jurnal Jurusan Manajemen Universitas Komputer Indonesia.

Zamroni, M. (2013). Perempuan dalam kajian komunikasi politik dan gender. Jurnal Dakwah, 14(1), 103-132. 